\title{
Observations on recent mass mortality events of marine mussels in the Oosterschelde, the Netherlands
}

\author{
Jacob J. Capelle, et al. [full author details at the end of the article]
}

Received: 28 October 2020 / Accepted: 29 April 2021/ Published online: 11 May 2021

(C) The Author(s) 2021

\begin{abstract}
Two mass mortality events (MMEs) of marine mussels that took place in the Oosterschelde, the Netherlands - the first in 2015/2016 and the second in 2019 - both severely affected mussel production. The current study presents our observations on the onset and course of both MMEs and discusses probable putative causes. The two MMEs displayed a distinct course of events. The first event started in November 2015 with high mortality rates on culture plots, which remained elevated until the autumn of 2016. Approximately $40-50 \%$ of mussels from all age classes were lost on culture plots and $100 \%$ were lost from wild seed beds. The second event started in April-May 2019 and continued until the end of July, with mortality ranging from 20 to $100 \%$, again from all age classes. Culture areas other than the Oosterschelde and other shellfish species were not affected. Histological and bacteriological screening produced no evidence for common pathogens or pollution as a primary mortality factor and there is no indication of abnormal environmental conditions preceding or during the events. We hypothesize that a cumulation of stressors results in weakening of the mussels and in elevated mortality rates. In 2019, this cumulation of stressors could be high spawning activities (an unusual high concentration of mussel larvae was found in April) that resulted in very low condition from April to June, a Phaeocystis bloom in April to May that prevented a quick recovery, and the development of granulocytomas that were found in up to 60 to $70 \%$ of live mussels as a consequence of cumulative stress. Although no (single) putative causes could be identified, this study contributes to the knowledge on MMEs in mussels and fits in a wider and disturbing trend on mortality events in shellfish.
\end{abstract}

Keywords Mass mortality event (MME) - Aquaculture · Climate change · Diseases · Shellfish · HABs

\footnotetext{
Highlights

- Timeline of recent mussel MMEs in the Netherlands are described

- No putative cause has yet been found

- MMEs were linked to a cumulation of stressors

- Stressors include spawning, drop in condition, and a Phaeocystis bloom

Handling Editor: Gavin Burnell
} 


\section{Introduction}

Mass mortality events (MMEs) are rapidly occurring catastrophic demographic events that punctuate background mortality levels (Fey et al. 2015). Adverse impacts of environmental conditions or disease outbreaks can result in MMEs that involve different species and taxa (for example, marine invertebrates, including sponges, cnidarians, bivalves, ascidians, and bryozoans in the northwestern Mediterranean (Perez et al. 2000)), or just a single species (such as infections by viral and bacterial pathogens in oysters (Solomieu et al. 2015)). MMEs can severely affect the commercial production of bivalve species and give rise to socio-economic vulnerabilities (Krause et al. 2019). Since 2014, MMEs of blue mussel stocks have been reported on a nearly yearly basis from the west coast of France (Dégremont et al. 2019). Mussels are an important aquaculture product in France and tools for reducing the economic consequence are limited (Avdelas et al. 2021). Despite the extensive research, a single explanation has not yet been found.

In the Netherlands, blue mussels (Mytilus edulis) occur on extensive natural beds, particularly in the Wadden Sea. Blue mussels are also the country's dominant aquaculture species, cultured on subtidal plots in the southwest (Oosterschelde) and the north (Wadden Sea) part of the country. MMEs of mussels are extremely rare in the Netherlands. The two events that have been described so far could both be linked to causes. The first of these MMEs, which occurred in the Oosterschelde in 1949, was attributed to the introduction of Mytilicola intestinalis. Mussel production dropped by $80 \%$ and mussel culture activities were moved to the Wadden Sea. Mortality was minimized by reducing mussel density and production was soon restored (Korringa 1950). A second recorded MME is described for 2001, when unusual high mortalities on culture plots in the western part of the Oosterschelde were attributed to anoxia caused by post-bloom sedimentation of Phaeocystis colonies (Peperzak and Poelman 2008).

Two additional MMEs have occurred in the Oosterschelde in recent years, but no putative cause has yet been found. From the autumn of 2015 until the summer of 2016, high mussel mortalities $(-40-50 \%)$ were observed on culture plots and extended over all mussel culture areas. Also, spat from seed mussel collectors and submerged longline culture was affected. A second MME of mussels occurred in spring 2019, which involved the entire Oosterschelde basin including extensive areas where mortality was close to $100 \%$. Submerged longline culture suffered less from this event. The present study aims to communicate the observations and research into possible causes of the recent MMEs in the Netherlands, as they seem to fit in a wider and disturbing trend.

\section{Timeline of recent mussel MMEs in the Oosterschelde}

In November of 2015, reports started to come in from government officials in the field and from mussel growers of unusual mortality rates of mussels from subtidal culture plots. Mussel densities on those plots were not different than usual, around $2-8 \mathrm{~kg} / \mathrm{m}^{2}$, with an increase in biomass with mussel size. High mortality rates remained elevated on bottom plots until autumn 2016, affecting all size classes of mussels. Meat content of mussels was within normal range, but dying mussels possessed a vitreous appearance. This MME was only observed in mussels; there were no reports of elevated mortalities of other shellfish or fish species in the Oosterschelde. In July 2016, new wild subtidal mussel seed beds were found at several locations at a scale atypical for the Oosterschelde. All wild mussel seed beds withered and 
mussel seeds died in August-September before stock assessment could take place. Harvest from mussel seed collectors in the central part of the Oosterschelde in 2016 were substantially lower (about half of the biomass) than they had been in previous years (Capelle and van Stralen 2017). Mussel spat settlement on the collectors and early development followed normal patterns until mid-July, but from mid-July onwards, seed condition deteriorated and mortality on the collectors raised before harvest (July-August). Also, yields after seeding on culture plots remained low.

Signals of unusual high mortality rates of mussels on culture plots emerged again in AprilMay 2019. These signals were confirmed by a routine monitoring program in which growth and survival of mussels was monitored. In this program, mussels from the same batch were redistributed over 12 culture areas in the Oosterschelde and survival was monitored monthly from April-October 2019. Those mussels were kept in baskets slightly elevated from the sea floor to avoid density effects. Results reveal the spatial and temporal development of the mortality event (Fig. 1). Mortality was first observed in the northern part and then in the central part of the Oosterschelde; here, $80-100 \%$ of mussels were lost, while mortality in the western part started later and varied between 20 and $80 \%$. The reason for the differences in spatial and temporal development is not known, but it is remarkable that mortality was lower and started later on plots that were situated closer to the inlet of the North Sea. The whole Oosterschelde basin is replenished by the North Sea, with a relatively long turnover time, driven by tide: i.e., 38.3 days for the western part, 104 days for the northern part, and 116 days for the eastern part of the basin (Jiang et al. 2019). High mortality continued until the end of July and affected all year classes of mussels indifferent of mussel origin (for example, transplanted from outside the basin, such as Wadden Sea or Ireland versus mussels that originated from seed mussel collectors in the Oosterschelde). Towed video monitoring and mussel sampling took place during the MME in 2019 on various subtidal mussel plots where high mortalities had occurred. No anomalies were observed apart from a high number of empty shells, and associated fauna like crabs and starfish were widely present and did not seem to have been affected.

One naturally recruited mussel seed bed that originated from 2018 was fished in June 2019, by which time $80-90 \%$ of the mussel seed was already dead and fishing activities had ceased. In contrast to the event in 2016, harvest results from seed collectors in autumn 2019 were above average, and showed good growth and survival after relay to bottom plots.

\section{Discussion of possible causes}

Causes of bivalve MMEs can sometimes be pinpointed to a single occurrence, such as diseases (Ward and Lafferty 2004), benign environmental conditions such as hypoxia (Dolmer et al. 1999), harmful algal blooms (HABs) (Shumway 1990), or temperature extremes (Werner and Rothhaupt 2008). Often, multiple factors are associated with MMEs, e.g., eight potential causes were identified in MMEs in cockles (Burdon et al. 2014), or lethal viral infections in oysters are affected by a range of environmental or even farming practices (Alfaro et al. 2019). Sometimes, putative causes remain unknown or uncertain. This could partly be because secondary effects may mask primary causes and high exposure to environmental agents often makes sure that all kinds of microbiota start to grow after shellfish are weakened (Morley 2010). Alternatively, it could be that primary causes are diverse or due to a combination of factors or changes in the environment, such as temperature or $\mathrm{pH}$ that weakens the immune system (Bibby et al. 2008, Mackenzie et al. 2014). The frequency of MMEs appears to have 

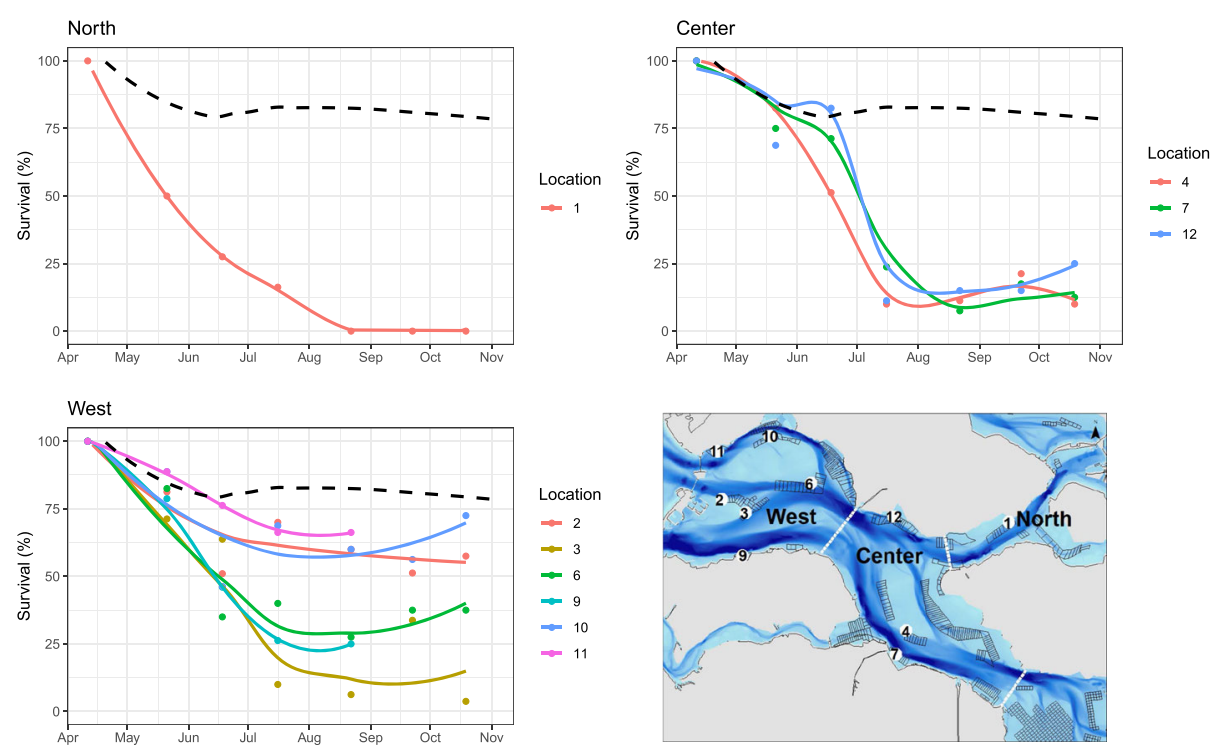

Fig. 1 Survival of mussels in 2019 from a monitoring program where mussels from similar origin were distributed in cages over 12 locations in the Oosterschelde. Lines show a loess smoother. Data from monthly sampling 1 cage with mussels without replacement. Dashed black line is the average survival over 2017 and 2018, when no mortality events took place. Numbers in legend refer to numbers in map. The three compartments (west, center, and north) that we refer to in the text are indicated in the topographic map of the Oosterschelde

increased in the last decennia and some authors have connected occurrences in fluctuations of large-scale stressors to variation in long-term processes, such as climate change or acidification (Lafferty et al. 2004; Ward and Lafferty 2004; Fey et al. 2015; Rogers-Bennett et al. 2019). No direct cause was found for the MMEs reported in this manuscript. However, some unusual patterns were observed. Described MMEs in bivalves can be summarized by considering the role of a causative agent, genetic effects, or adverse environmental conditions.

\section{Causative agent}

Research in France revealed that survivors of the MME showed elevated mortality rates in the following year and, when brought in contact with naïve mussels, mortality increased among the naïve mussels (Benabdelmouna et al. 2018). This suggests a horizontal transmissible agent. A pathogenic Vibrio stain (Vibrio splendidus) was predominantly present in moribund mussels from MMEs in Charente-Maritime (France) (Oden et al. 2016). Oden et al. (2016) hypothesize that Vibrio splendidus could either be a causative agent or invaders into the necrotic mussel tissues from the environment.

In the Oosterschelde, mussels were collected from three locations (near location 6 and location 4 in Fig. 1) in August 2016 and screened by histology and bacteriology for known pathogenic bacteria (i.e., Vibrio aestuarianus and Vibrio splendidus), parasites, and anomalies (Bower et al. 1994). No bacterial or parasitic infections that could explain the mortality events were observed nor were there indications for viral infections or neoplasia in the samples. Mussels were in good condition, with sufficient energy reserves, no anomalies were found in the digestive tract and gills, and no atresia was found in reproductive tissues. However, by histopathology, an increased number of mussels with granulocytomas (non-neoplastic clusters 
of granular hemocytes) was observed. From a mussel sample near location 6 (Fig. 1), 30\% of the mussels showed single or multiple granulocytomas in the connective tissues, and near location 4 (Fig. 1), 50-70\% of the mussels showed single or multiple granulocytomas in the connective tissues. The reference value of numbers of granulocytomas in mussels over the period 2006-2009 in the same area was approximately 6\% (unpublished data, Wageningen Bioveterinary Research). The presence of granulocytomas was not associated with any detectable pathogenic agent and is generally considered as an indicator of chronic stress (Lowe and Moore 1979).

In May 2019, following the reports of mass mortality, a histological and bacteriological screening was carried out, according to the same methodology as used in 2016 (Bower et al. 1994). Two mussel batches were analyzed, one from the northern part (near location 1 in Fig. 1) and one from the central part of the Oosterschelde (near location 4 in Fig. 1). Again, no indications for bacteria, parasites, or neoplasia as a causative agent to the ongoing mortality were found. Contrary to 2016, mussels from the samples were in poor condition and high number of ciliates was present in the gills. Despite their non-pathogenic status, high concentrations of ciliates in shellfish gills can cause localized cell damage and an excess of mucus production can cause disruption of food particle transport across epithelial surface (McGurk et al. 2016) and respiratory impartment (Boussaid et al. 1999). The percentage of mussels with granulocytomas was high in the northern part of the Oosterschelde $(\sim 63 \%)$, but close to reference levels in the central part $(\sim 7 \%)$.

Although mussels were screened on commonly known pathogens, it cannot be excluded that a relative unknown pathogen plays a significant role. For example, in France, the bacteria Francisella halioticida, associated with mass mortalities in abalones and scallops, was detected within inflammatory granulomas in mussels that experienced high mortality (Charles et al. 2020). In addition, vulnerability of mussels for pathogens might differ between life stages. For example, at vulnerable stages, such as during spawning, pathogenic effects might become prevalent (Charles et al. 2019b).

Genetic abnormalities related to an ongoing neoplastic process were measured in mussels during MMEs in France in 2015 and 2016 (Benabdelmouna and Ledu 2016). No signs of neoplasia were found in histological analyses in 2016 and 2019 from mussels in the Oosterschelde, and it probably was not the putative cause of the MMEs in France either (Burioli et al. 2019). However, neoplasia can potentially have a large effect; for example, it has caused significant mortalities in Mytilus trossulus in the USA (Elston et al. 1992). Therefore, indications of neoplasia should be part of future monitoring programs.

\section{Genetic effects}

Genetic factors affect mussels' susceptibility to mortality. For instance, reduced degrees in heterozygosity resulted in higher losses after exposure to stress, linked to increased maintenance requirements in homozygous mussels (Hawkins et al. 1986; Tremblay et al. 1998; Myrand et al. 2002). Hybridization also has an effect; Mytilus galloprovincialis and Mytilus edulis $\times$ M. galloprovincialis hybrids were was less susceptible to mortality than pure M. edulis (Benabdelmouna et al. 2018). Mussels in the Oosterschelde are almost pure M. edulis, with a small amount of M. galloprovincialis alleles (Kijewski et al. 2019). Also, survivors from a MME in France displayed significant higher survival rates than naive mussels during a second mortality event (Benabdelmouna et al. 2018). Further experimental evidence for a genetic base comes from a selective breeding experiment of mussels for increasing 
resistance to the spring mortality. Progeny of survivors showed less mortality in the following outbreak, indicating a significant genetic improvement for the selected trait, while the putative agent remains still unknown (Dégremont et al. 2019). We do not know the extent to which genetic factors affected the mortality outbreaks in the Oosterschelde. During the outbreaks, different year classes of mussels that were farmed in the Oosterschelde originated from different regions (Wadden Sea, Ireland, local, etc.); this was not different from other years and there was no obvious relation between mortality rates with origin, or size class. However, breeding programs can be a successful tool for increasing resistance to diseases in aquatic animals (Gjedrem and Rye 2018), and when MMEs occur more regularly in the future, a breeding program can be part of a solution.

\section{Environmental conditions}

Mussels display an increase in the prevalence of granulocytomas and neoplasia after exposure to environmental contaminants, such as diesel oil or copper (Auffret 1988; Benabdelmouna and Ledu 2016). Spatial patterns of mortality outbreaks in France suggest no obvious link with pollution as a cause for the mortality (Charles et al. 2019a). The Oosterschelde is closed off from river influences and has low levels of pollution (ten Brinke et al. 1994; Tangelder et al. 2015). Dyke reinforcements with rock droppings took place in the Oosterschelde in 2016 and pollutants that potentially leach from the rocks, especially vanadium from steel slags could be a cause for chronic stress. A preliminary experiment was carried out to determine granulocytoma development in mussels when exposed to these rocks, but the results were inconclusive (Escaravage and Kamermans 2018). Mesocosm experiments revealed that steel slags cause a short-term elevation of $\mathrm{pH}$, but no effect on benthos was found (Foekema et al. 2016). We are not aware of any further signals that suggest different pollution levels during the mortality events than in other years.

The cumulation of adverse environmental conditions can weaken mussels and make them more susceptible to mortality from conditions that they are able to cope with under normal circumstances (Delorme et al. 2020). This is also dependent on the health status of the mussel. Mussels are most vulnerable during and shortly after reproduction when food reserves are exhausted (Pieters et al. 1980). Environmental stress in this period can result in high mortality rates; for example, stressful temperatures in spawning period caused extensive summer mortality in mussel culture in Canada (Mallet and Carver 1989; Myrand et al. 2000).

Since 2017, abundance of mussel larvae has been monitored on a weekly basis in the Oosterschelde and Wadden Sea. Spring 2019 was exceptional in terms of the high number of larvae that were observed in the Oosterschelde (Fig. 2) compared to other years. Since 2014, the condition of mussels on culture plots has been monitored year-round on 10-12 culture plots on a monthly basis at different locations in the Oosterschelde. Pre-spawning mussel condition (expressed as the percentage of cooked meat per wet weight) measured in mussels from the routine monitoring program was around average in the winter of 2015-2016 and in the winter of 2018-2019. Spawning occurs in early spring and normally after spawning condition quickly recovers to levels over $20 \%$ due to good feeding conditions in late spring (spring algae bloom). However, in spring and summer 2019, after the high reproductive activity, the condition of mussels remained exceptionally low (Fig. 3).

It is remarkable that two local MMEs occurred quite recently without precedent. There are emerging examples of climate change effects on aquaculture species at different areas in the world, notably rising water temperatures, acidification, and changes in environment and food 


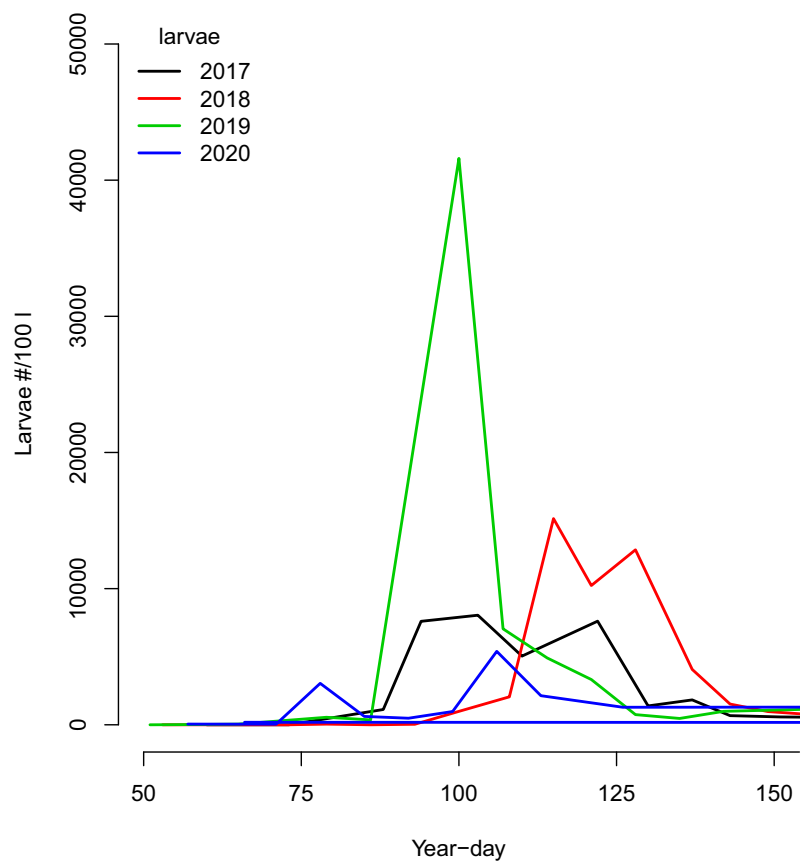

Fig. 2 Number of mussel larvae per 100 liters in the Oosterschelde (station Neeltje Jans), results from weekly sampling

webs (Reid et al. 2019). Water temperature in the Oosterschelde shows an increasing trend: the average water temperature increased approximately $1.5^{\circ} \mathrm{C}$ between 1990 and 2018 (Fig. 5). Temperature can act as direct stressor by affecting respiratory responses; at high temperatures, the threshold of maximum thermal sensitivity of the metabolic rate (between 24 and $31{ }^{\circ} \mathrm{C}$ for M. edulis) can be crossed, which can ultimately result in death (Jansen et al. 2007). Maximum summer temperatures in the Oosterschelde peak were just below $24{ }^{\circ} \mathrm{C}$. At some locations in the basin, it will occasionally get higher than that, but there are no indications (for example, in spatial mortality patterns or for littoral locations) that temperature effects on physiologic rates are related to MMEs in mussels yet. Temperature also shows a negative correlation with gametogenesis and spawning is temperature related; that is, mild winters (such as that of 20182019) and high water temperatures in early spring will negatively affect gametogenesis and advance spawning, and when water temperatures are relatively cold in early spring (such as in 2017-2018), spawning is delayed (see also Fig. 2) (de Vooys 1999; Fearman and Moltschaniwskyj 2010). There is no evidence that suggest a primary effect of temperature; mussel culture is carried out on subtidal culture plots (2-20 m below surface), where temperatures are lower with depth and there is no indication for higher losses at shallower plots. However, timing and composition of phytoplankton blooms and marine food webs are also affected by temperature (Müren et al. 2005); analysis of long-term time series shows an advancement of the spring bloom in the Netherlands in recent periods (Philippart et al. 2010). Harmful algal blooms (HABs) are often caused by toxin-producing species and monitored to prevent harm to humans after shellfish consumption. However, toxin production is not the only pathway via which harmful algae can exert a negative effect; HABs can also affect shellfish in their behavior, and at the tissue, cellular, and molecular level (Basti et al. 2018). In April-May 

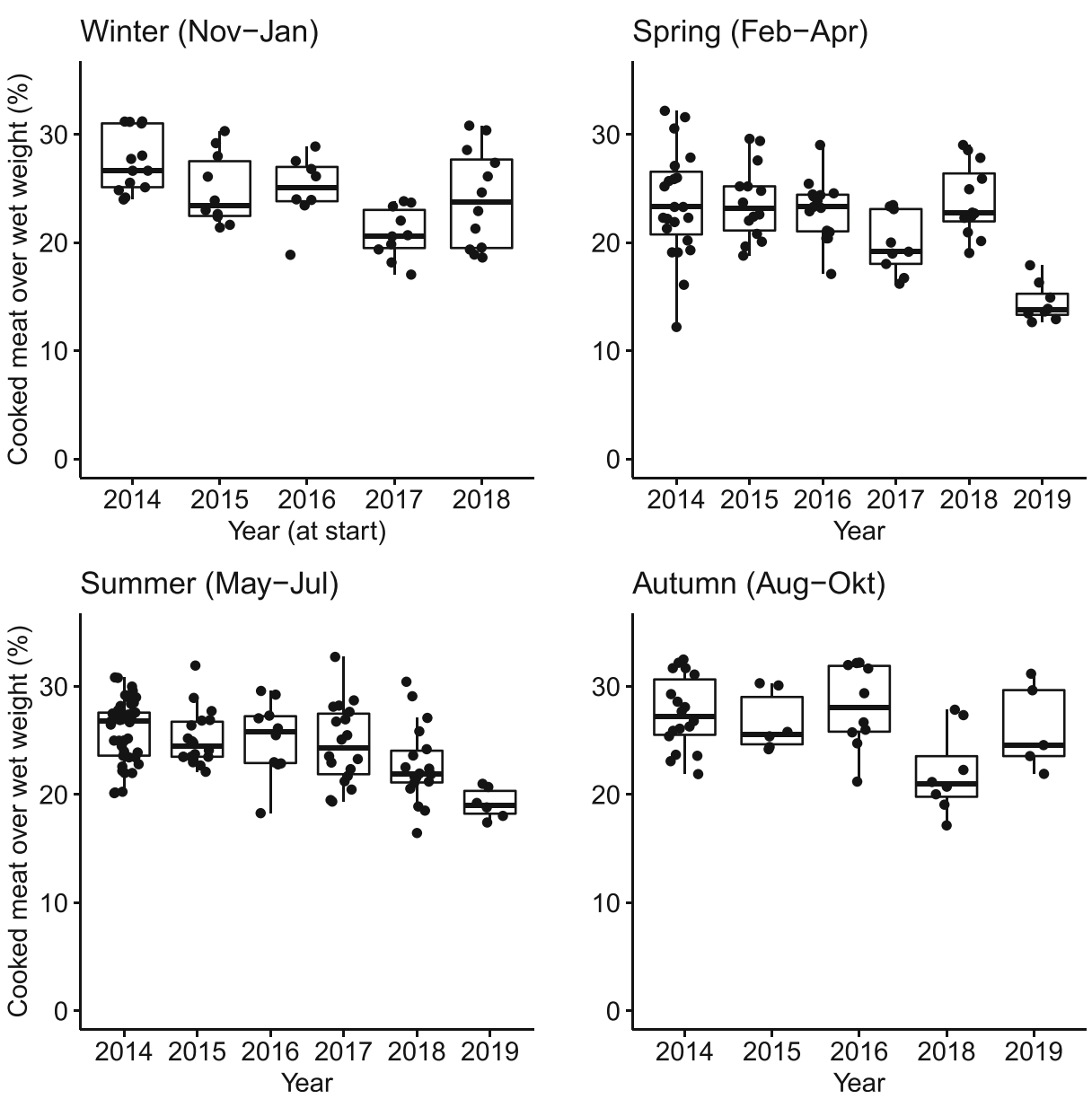

Fig. 3 Mussel condition (percentage of cooked flesh weight over wet weight) from a routine monitoring program; each dot represents a sample of at least 30 mussels

2019, a dominant bloom of Phaeocystis sp. occurred all over the Oosterschelde, with maximum counts of $24.7 \mathrm{mln}$ cells/1 (Fig. 4). A bloom of a similar extend (max. counts of $24.5 \mathrm{mln}$ cells/1) occurred in 2013 only about 25 year-days later, and in 2010, a high number of Phaeocystis cells were counted too (max. count $21.3 \mathrm{mln}$ cells/l), although the duration of the bloom was shorter than in 2019 (Fig. 4). Phaeocystis is an algae that can serve as food for mussels when it occurs as single cells (Smaal and Twisk 1997). When Phaeocystis forms glutinous colonies, they can have several secondary adverse effects on mussels. The glutinous colonies can clog the gills of the mussels (Kopp 1978) and reduce clearance rates (Prins et al. 1994). This reduces growth and delays gonad recovery (Pieters 1978). Phaeocystis are present in the entire water column, causing high oxygen concentrations during the day, but might cause hypoxia at night (for example, Kopp (1978) measured an oxygen oversaturation of $200 \%$ during the day, while levels reached $0 \%$ near the bottom during the night). When the bloom collapses, dead algae with mucus sink to the bottom, forming a decaying layer that can cause hypoxia and high nutrient levels at the sea floor (Peperzak 2002). This effect was connected to mass mortality of mussels in the Oosterschelde in 2001, with cell counts of 40 
$\mathrm{mln} / 1$ in the near shore North Sea, but only $2 \mathrm{mln} / 1$ at the Oosterschelde (Peperzak and Poelman 2008). During the MME in 2019, oxygen loggers were placed just above the sea floor at two different locations (center and west, Fig. 1) from mid-May until the end of June. Oxygen loggers showed no proof of hypoxic events; oxygen concentration did not drop below 6-8 mg/l.

Trends in $\mathrm{pH}$ and chl a since 1990 show fluctuations, but no significant decline or incline (Fig. 5).

\section{Synthesis}

No putative cause can be found for the MME of mussels in the Oosterschelde in 2016 and 2019. A timeline of events and conditions during and preceding the MMEs are summarized in Table 1. Remarkably, both MMEs followed a different pattern and the MMEs only occurred in mussels in the Oosterschelde; other culture areas (that is Wadden Sea) and other shellfish species were not affected. Furthermore, there is no history in the Oosterschelde of such MMEs occurring without a susceptible cause. Pathogens could explain the indiscriminate nature of the event, affecting mussels from all year classes and origins and not affecting other shellfish. However, pathogens were not detected at levels that are required for such events to occur. It should be noted that testing is only done for common pathogens, and an uncommon pathogen can remain undetected. There is no evidence for pollution as a mortality factor, but this has not been studied extensively. Research from other places in the world show that genetic factors affect susceptibility for mortality and breeding experiments offer perspectives for selection. However, the question remains, why would there be MMEs in certain years and not in others, if seed from the same origin is used year after year, and if they have the same genetic makeup?

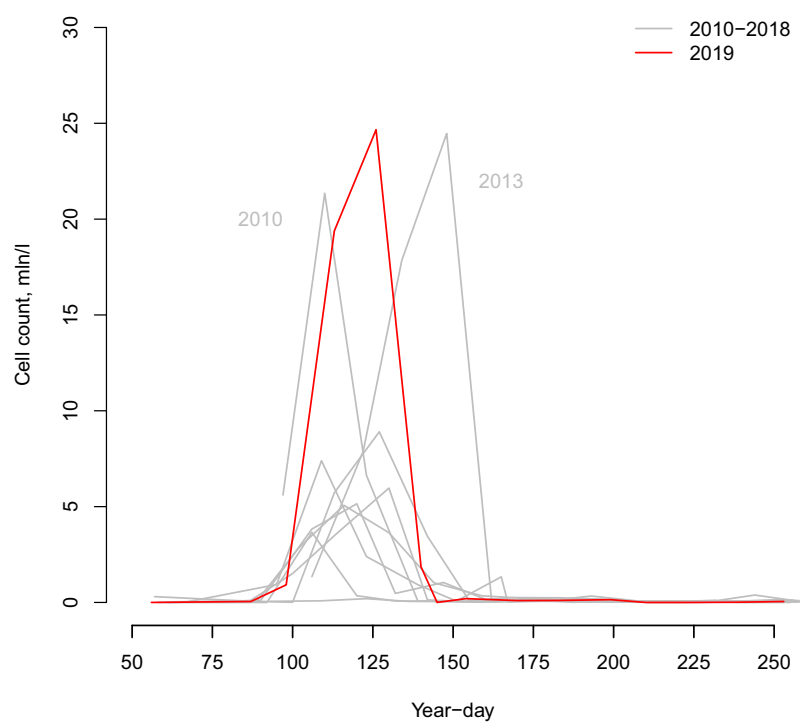

Fig. 4 Number of Phaeocystis cells (all stadia) in million per liter; data received from Bureau WaardenburgEcologie en Landschap 

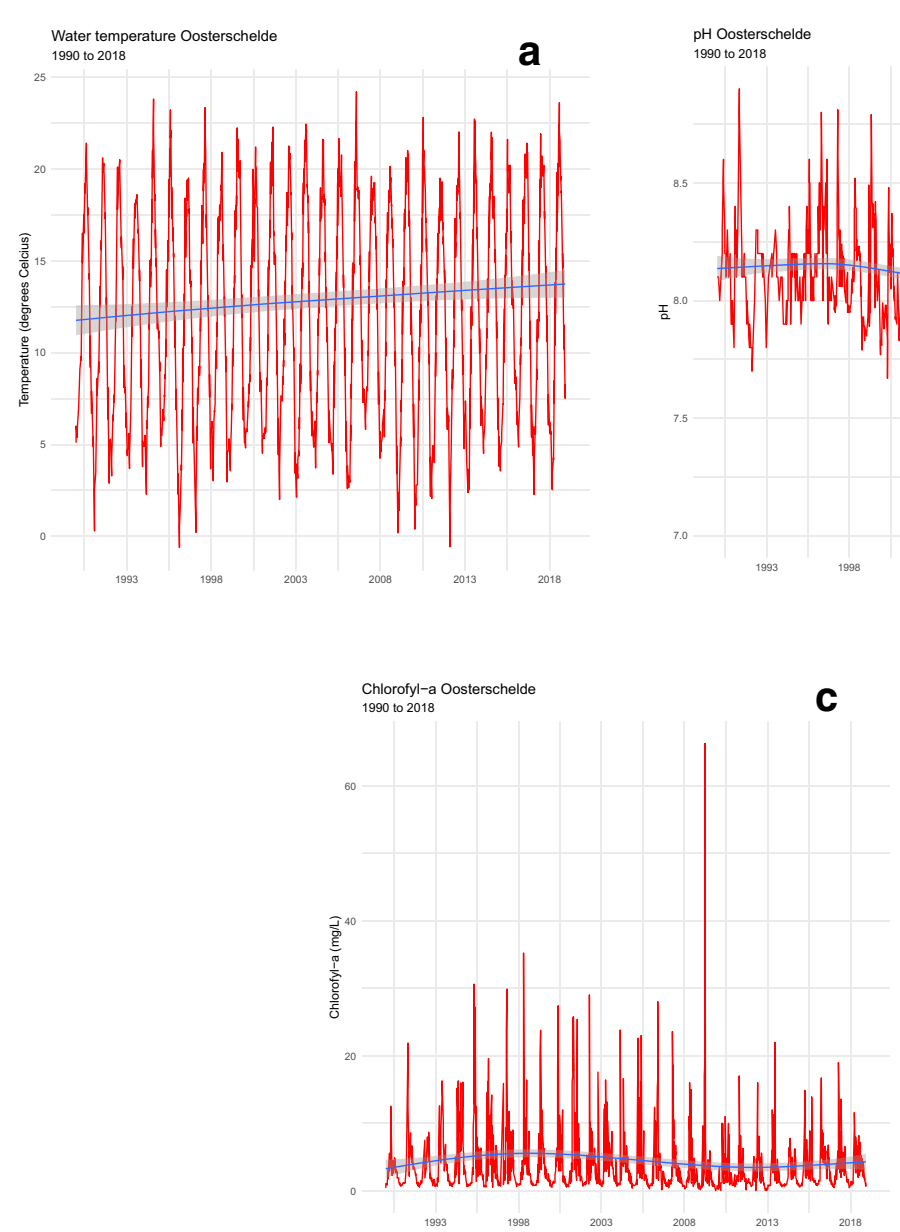

Fig. 5 Time series of a water temperature, $\mathbf{b}$ pH, and $\mathbf{c}$ chl a in Oosterschelde from 1990 to 2018; line is a loess smoother (source: https://waterinfo.rws.nl/)

There are some similarities to recent MMEs from the west coast of France. In particular, the occurrence of a "mortality window" was mentioned by Charles et al. (2019a) when a cumulation of stressors results in weakening of the mussels and in elevated mortality rates. In 2019, this cumulation of stressors might be high spawning activities that resulted in very low condition, a Phaeocystis bloom that prevented a quick recovery, and the development of granulocytomas as a consequence of the cumulative stress that might explain ongoing mortality during the summer season. The development of granulocytomas was high only in the northern part of the Oosterschelde for 2019. It remains unknown what triggered high spawning activities in 2019 that most likely resulted in very low condition of the mussels. It also remains unknown what triggered the MME that started in November 2015 and resulted in the losses from the spat mussel collectors and in the death of all wild mussel beds in the early autumn of 2016.

We advocate a standard monitoring of mussel mortality on culture sites to get a better idea of the source and chain of events and to start monitoring the environment and mussels when unusual mortality signals arise. In addition, we advise preserving mussel samples on a regular basis to measure relevant parameters in retrospect, in case another MME occurs in the near future. 


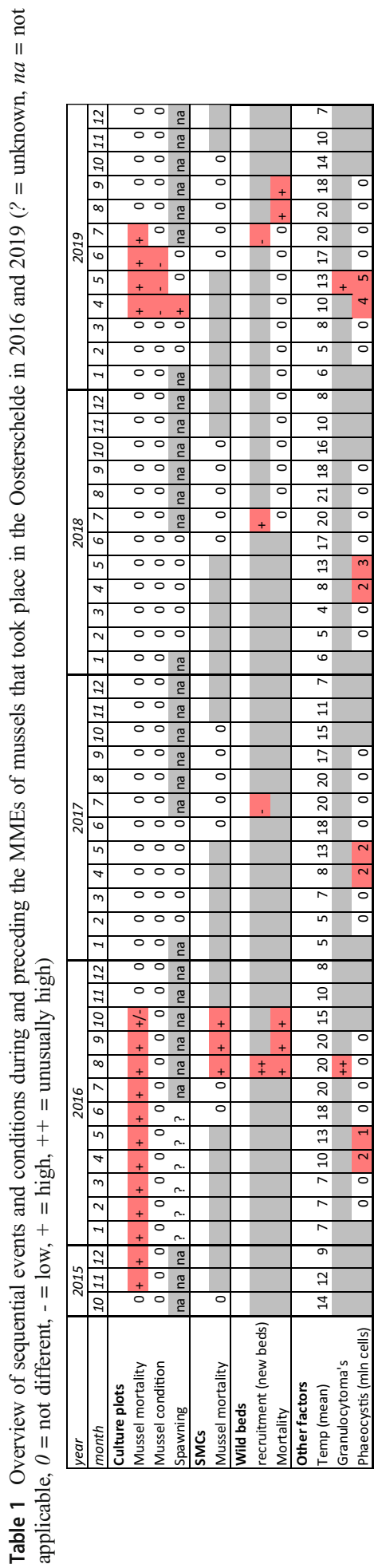


Acknowledgements We thank Marinus Padmos for providing mussel samples from his culture plots in the Oosterschelde and Lisanne van den Bogaart (WMR) for providing environmental data. We thank three anonymous reviewers for comments that improved the quality of this manuscript.

Author contributions All authors contributed to the study conception and design. Material preparation, data collection, and analysis were performed by JJC, ABG, and MYE. The first draft of the manuscript was written by $\mathrm{JJC}$ and all authors commented on previous versions of the manuscript. All authors read and approved the final manuscript.

Funding Monitoring data on mussel growth and larval abundance were collected within the INNOPRO program, funded by the European Fisheries Fund and by the Dutch Producers Organization of Mussel culture (POM). The work of MYE was supported by the Ministry of Agriculture, Nature and Food Quality (WOT-01002-004.06). The work of JJC and ABG was (co)funded by the European Fisheries Fund, and the work of JJC, ABG, PK, and HMJ was (co)funded by the Dutch Producers Organization of Mussel culture (POM). The work of MYE was supported by the Ministry of Agriculture, Nature and Food Quality (WOT-01-002-004.06).

\section{Declarations}

Ethics approval This article does not contain any studies with animals performed by any of the authors.

Conflict of interest The authors declare no competing interests.

Open Access This article is licensed under a Creative Commons Attribution 4.0 International License, which permits use, sharing, adaptation, distribution and reproduction in any medium or format, as long as you give appropriate credit to the original author(s) and the source, provide a link to the Creative Commons licence, and indicate if changes were made. The images or other third party material in this article are included in the article's Creative Commons licence, unless indicated otherwise in a credit line to the material. If material is not included in the article's Creative Commons licence and your intended use is not permitted by statutory regulation or exceeds the permitted use, you will need to obtain permission directly from the copyright holder. To view a copy of this licence, visit http://creativecommons.org/licenses/by/4.0/.

\section{References}

Alfaro AC, Nguyen TV, Merien F (2019) The complex interactions of Ostreid herpesvirus 1, Vibrio bacteria, environment and host factors in mass mortality outbreaks of Crassostrea gigas. Rev Aquac 11:1148-1168

Auffret M (1988) Histopathological changes related to chemical contamination in Mytilus edulis from field and experimental conditions. Marine Ecol-Progr Ser 46:101-107

Avdelas L, Avdic-Mravlje E, MarqueS ACB, Cano S, Capelle JJ, Carvalho N, Cozzolino M, Dennis J, Ellis T, Polanco JMF, Guillen J, Lasner T, Le Bihan V, Llorente I, Mol A, Nicheva S, Nielsen R, Oostenbrugge H, Villasante S, Visnic S, Zhelev K, Asche F (2021) The decline of mussel aquaculture in the European Union: causes, economic impacts and opportunities. Rev Aquacult 13(1):91-118

Basti L, Hégaret H, Shumway SE (2018) Harmful algal blooms and shellfish. Harmful algal blooms: a compendium desk reference. John Wiley \& Sons, Ltd., Hoboken, pp 135-190

Benabdelmouna A, Ledu C (2016) The mass mortality of blue mussels (Mytilus spp.) from the Atlantic coast of France is associated with heavy genomic abnormalities as evidenced by flow cytometry. J Invertebr Pathol 138:30-38

Benabdelmouna A, Garcia C, Ledu C, Lamy P, Maurouard E, Dégremont L (2018) Mortality investigation of Mytilus edulis and Mytilus galloprovincialis in France: an experimental survey under laboratory conditions. Aquaculture 495:831-841

Bibby R, Widdicombe S, Parry H, Spicer J, Pipe R (2008) Effects of ocean acidification on the immune response of the blue mussel Mytilus edulis. Aquat Biol 2:67-74

Boussaid B, Grippari JL, Renault T, Tige G, Dorange G (1999) Trichodina sp. Infestation of Crassostrea gigas Oyster Gills in Brittany, France. J Invertebr Pathol 73:339-342 
Bower SM, McGladdery SE, Price IM (1994) Synopsis of infectious diseases and parasites of commercially exploited shellfish. Annu Rev Fish Dis 4:1-199

Burdon D, Callaway R, Elliott M, Smith T, Wither A (2014) Mass mortalities in bivalve populations: a review of the edible cockle Cerastoderma edule (L.). Estuarine. Coastal Shelf Sci 150:271-280

Burioli EAV, Trancart S, Simon A, Bernard I, Charles M, Oden E, Bierne N, Houssin M (2019) Implementation of various approaches to study the prevalence, incidence and progression of disseminated neoplasia in mussel stocks. J Invertebr Pathol 168:107271

Capelle JJ, van Stralen MR (2017) Invang mosselzaad in MZIs, resultaten 2016. C044/17. Wageningen Marine Research, Yerseke

Charles M, Bernard I, Villalba A, Oden E, Burioli EA, Allain G, Trancart S, Bouchart V, Houssin M (2019a) High mortality of mussels in northern Brittany-evaluation of the involvement of pathogens, pathological conditions and pollutants. J Invertebr Pathol 170:107308

Charles M, Trancart S, Oden E, Houssin M (2019b) Experimental infection of Mytilus edulis by two Vibrio splendidus-related strains: determination of pathogenicity level of strains and influence of the origin and annual cycle of mussels on their sensitivity. J Fish Dis

Charles M, Villalba A, Meyer G, Trancart S, Lagy C, Bernard I, Houssin M (2020) First detection of Francisella halioticida in mussels Mytilus spp. experiencing mortalities in France. Dis Aquat Org 140:203-208

de Vooys CGN (1999) Numbers of larvae and primary plantigrades of the mussel Mytilus edulis in the western Dutch Wadden Sea. J Sea Res 41:189-201

Dégremont L, Maurouard E, Rabiller M, Glize P (2019) Response to selection for increasing resistance to the spring mortality outbreaks in Mytilus edulis occurring in France since 2014. Aquaculture 511:734269

Delorme N, Biessy L, South P, Zamora L, Ragg NLC, Burritt D (2020) Stress-on-stress responses of a marine mussel (Perna canaliculus): food limitation reduces the ability to cope with heat stress in juveniles. Mar Ecol Prog Ser 644:105-117

Dolmer P, Kristensen PS, Hoffmann H (1999) Dredging of blue mussels (Mytilus edulis L.) in a Danish sound: stock sizes and fishery-effects on mussel population dynamic. Fish Res 40 (1):73-80

Elston R, Moore J, Brooks K (1992) Disseminated neoplasia of bivalve mollusks. Rev Aquat Sci 6:405-466

Escaravage, V., and P. Kamermans. 2018. Mosselen in troebel water; Het effect van stof van breuksteen en staalslakken op mosselen. Wageningen Marine Research Wageningen UR, Wageningen Marine Research rapport C077/18. 24 blz.

Fearman J, Moltschaniwskyj NA (2010) Warmer temperatures reduce rates of gametogenesis in temperate mussels, Mytilus galloprovincialis. Aquaculture 305:20-25

Fey SB, Siepielski AM, Nusslé S, Cervantes-Yoshida K, Hwan JL, Huber ER, Fey MJ, Catenazzi A, Carlson SM (2015) Recent shifts in the occurrence, cause, and magnitude of animal mass mortality events. Proc Natl Acad Sci 112:1083-1088

Foekema, E. M., M. J. Van den Heuvel-Greve, C. Sonneveld, G. Hoornsman, and A. Blanco Garcia. 2016. Uitloging en effecten van metalen uit staalslakken beoordeeld in mesocosms. (Rapport / IMARES; No. C063/16). IMARES Wageningen UR. Yerseke.

Gjedrem T, Rye M (2018) Selection response in fish and shellfish: a review. Rev Aquac 10:168-179

Hawkins A, Bayne B, Day A, Denton EJ (1986) Protein turnover, physiological energetics and heterozygosity in the blue mussel, Mytilus edulis: the basis of variable age-specific growth. Proceedings of the Royal society of London. Series B. Biologic Sci 229:161-176

Jansen JM, Pronker AE, Kube S, Sokolowski A, Sola JC, Marquiegui MA, Schiedek D, Wendelaar Bonga S, Wolowicz M, Hummel H (2007) Geographic and seasonal patterns and limits on the adaptive response to temperature of European Mytilus spp. and Macoma balthica populations. Oecologia 154:23-34

Jiang L, Gerkema T, Wijsman JWM, Soetaert K (2019) Comparing physical and biological impacts on seston renewal in a tidal bay with extensive shellfish culture. J Mar Syst 194:102-110

Kijewski T, Zbawicka M, Strand J, Kautsky H, Kotta J, Rätsep M, Wenne R (2019) Random forest assessment of correlation between environmental factors and genetic differentiation of populations: case of marine mussels Mytilus. Oceanologia 61:131-142

Kopp, J. 1978. Les phénomènes d'eaux colorées ayant affecté le littoral Bas-Normand au cours du mois de juin 1978. Inst. Sci. Tech. Peches Mar., Centre de Ouistreham, 30 pp.

Korringa P (1950) De aanval van de parasiet Mytilicola intestinalis op de Zeeuwse mosselcultuur. VisserijNieuws 7:1-7

Krause G, Buck BH, Breckwoldt A (2019) Socio-economic aspects of marine bivalve production, Goods and Services of Marine Bivalves. Springer, Cham, pp 317-334

Lafferty KD, Porter JW, Ford SE (2004) Are diseases increasing in the ocean? Annu Rev Ecol Evol Syst 35:3154

Lowe DM, Moore MN (1979) The cytology and occurrence of granulocytomas in mussels. Mar Pollut Bull 10: $137-141$ 
Mackenzie CL, Lynch SA, Culloty SC, Malham SK, Jiravanichpaisal P (2014) Future oceanic warming and acidification alter immune response and disease status in a commercial shellfish species, Mytilus edulis L.. PLoS ONE 9(6):e99712

Mallet AL, Carver CEA (1989) Growth, mortality, and secondary production in natural populations of the blue mussel, Mytilus edulis. Can J Fish Aquat Sci 46:1154-1159

McGurk ES, Ford S, Bushek D (2016) Unusually abundant and large ciliate xenomas in oysters, Crassostrea virginica, from Great Bay, New Hampshire, USA. J Invertebr Pathol 137:23-32

Morley NJ (2010) Interactive effects of infectious diseases and pollution in aquatic molluscs. Aquat Toxicol 96: 27-36

Müren U, Berglund J, Samuelsson K, Andersson A (2005) Potential effects of elevated sea-water temperature on pelagic food webs. Hydrobiologia 545:153-166

Myrand B, Guderley H, Himmelman JH (2000) Reproduction and summer mortality of blue mussels Mytilus edulis in the Magdalen Islands, southern Gulf of St. Lawrence. Mar Ecol Prog Ser 197:193-207

Myrand B, Tremblay R, Sévigny J-M (2002) Selection against blue mussels (Mytilus edulis L.) homozygotes under various stressful conditions. J Hered 93:238-248

Oden E, Burioli E, Trancart S, Pitel P, Houssin M (2016) Multilocus sequence analysis of Vibrio splendidus related-strains isolated from blue mussel Mytilus sp. during mortality events. Aquaculture 464:420-427

Peperzak L (2002) The wax and wane of Phaeocystis globosa blooms, PhD Thesis. University Library Groningen

Peperzak L, Poelman M (2008) Mass mussel mortality in The Netherlands after a bloom of Phaeocystis globosa (prymnesiophyceae). J Sea Res 60:220-222

Perez T, Garrabou J, Sartoretto S, Harmelin JG, Francour P, Vacelet J (2000) Massive mortality of marine invertebrates: an unprecedented event in northwestern Mediterranean. Comptes rendus de l'Academie des sciences. Serie III, Sci de la vie 323:853-865

Philippart CJM, Van Iperen JM, Cadée GC, Zuur AF (2010) Long-term field observations on seasonality in chlorophyll-a concentrations in a shallow coastal marine ecosystem, the Wadden Sea. Estuar Coasts 33: 286-294

Pieters, H. 1978. Seizoensvariaties in konditie en biochemische samenstelling van mosselen (Mytilus edulis L.), afkomstig uit de waddenzee. . RIVO, IJmuiden.

Pieters H, Kluytmans JH, Zandee DI, Cadée GC (1980) Tissue composition and reproduction of Mytilus edulis in relation to food availability. Neth J Sea Res 14:349-361

Prins TC, Dankers N, Smaal AC (1994) Seasonal variation in the filtration rates of a semi-natural mussel bed in relation to seston composition. J Exp Mar Biol Ecol 176:69-86

Reid GK, Gurney-Smith HJ, Marcogliese DJ, Knowler D, Benfey T, Garber AF, Forster I, Chopin T, BrewerDalton K, Moccia RD (2019) Climate change and aquaculture: considering biological response and resources. Aquacult Environ Interact 11:569-602

Rogers-Bennett L, Kashiwada JV, Taniguchi IK, Kawana SK, Catton CA (2019) Using density-based fishery management strategies to respond to mass mortality events. J Shellfish Res 38:485-495

Shumway SE (1990) A review of the effects of algal blooms on shellfish and aquaculture. J World Aquacult Soc 21:65-104

Smaal AC, Twisk F (1997) Filtration and absorption of Phaeocystis cf. globosa by the mussel Mytilus edulis L. J Exp Mar Biol Ecol 209:33-46

Solomieu VB, Renault T, Travers M-A (2015) Mass mortality in bivalves and the intricate case of the Pacific oyster, Crassostrea gigas. J Invertebr Pathol 131:2-10

Tangelder, M., M. J. Van den Heuvel-Greve, M. De Kluijver, S. T. Glorius, and H. M. Jansen. 2015. Monitoring vooroeververdediging Oosterschelde en Westerschelde 2014. (Rapport/IMARES; No. C102/15). IMARESYerseke.

ten Brinke WBM, Dronkers J, Mulder JPM (1994) Fine sediments in the Oosterschelde tidal basin before and after partial closure. In: Nienhuis PH, Smaal AC (eds) The Oosterschelde Estuary (The Netherlands): a CaseStudy of a Changing Ecosystem. Springer Netherlands, Dordrecht, pp 41-56

Tremblay R, Myrand B, Sevigny J-M, Blier P, Guderley H (1998) Bioenergetic and genetic parameters in relation to susceptibility of blue mussels, Mytilus edulis (L.) to summer mortality. J Exp Mar Biol Ecol 221:27-58

Ward JR, Lafferty KD (2004) The elusive baseline of marine disease: are diseases in ocean ecosystems increasing? PLoS Biol 2:E120

Werner S, Rothhaupt KO (2008) Mass mortality of the invasive bivalve Corbicula fluminea induced by a severe low-water event and associated low water temperatures. Ecological Effects of Water-Level Fluctuations in Lakes. Springer. pp 143-150 
Publisher's note Springer Nature remains neutral with regard to jurisdictional claims in published maps and institutional affiliations.

\section{Affiliations}

Jacob J. Capelle ${ }^{1}$ - Ainhoa Blanco Garcia ${ }^{1}$ - Pauline Kamermans ${ }^{1} \cdot$ Marc Y. Engelsma $^{2}$. Henrice M. Jansen ${ }^{1}$

Jacob J. Capelle

jacob.capelle@wur.nl

1 Wageningen Marine Research, Wageningen University and Research, PO Box 77, 4400 ABYerseke, The Netherlands

2 Wageningen Bioveterinary Research, Wageningen University and Research, PO Box 65, 8200 ABLelystad, The Netherlands 